\title{
Enzymatic capacities of metabolic fuel use in cuttlefish (Sepia officinalis) and responses to food deprivation: insight into the metabolic organization and starvation survival strategy of cephalopods
}

\author{
Ben Speers-Roesch ${ }^{1} \cdot$ Neal I. Callaghan ${ }^{2}$ Tyson J. MacCormack ${ }^{2}$. \\ Simon G. Lamarre ${ }^{3} \cdot$ Antonio V. Sykes $^{4} \cdot$ William R. Driedzic ${ }^{1}$
}

Received: 14 December 2015 / Revised: 27 March 2016 / Accepted: 13 April 2016 / Published online: 30 April 2016

(C) Springer-Verlag Berlin Heidelberg 2016

\begin{abstract}
Food limitation is a common challenge for animals. Cephalopods are sensitive to starvation because of high metabolic rates and growth rates related to their "live fast, die young" life history. We investigated how enzymatic capacities of key metabolic pathways are modulated during starvation in the common cuttlefish (Sepia officinalis) to gain insight into the metabolic organization of cephalopods and their strategies for coping with food limitation. In particular, lipids have traditionally been considered unimportant fuels in cephalopods, yet, puzzlingly, many species (including cuttlefish) mobilize the lipid stores in their digestive gland during starvation. Using a comprehensive multi-tissue assay of enzymatic capacities for energy metabolism, we show that, during long-term starvation (12 days), glycolytic capacity for glucose use is decreased in cuttlefish tissues, while capacities for use of lipid-based fuels (fatty acids and ketone bodies) and amino acid fuels are retained or increased. Specifically, the capacity to use the ketone body acetoacetate as fuel is widespread across tissues and gill has a previously unrecognized capacity for fatty acid catabolism, albeit at low rates. The capacity for
\end{abstract}

Communicated by H.V. Carey.

Ben Speers-Roesch

bspeersr@gmail.com

1 Department of Ocean Sciences, Memorial University of Newfoundland, St. John's, NL A1C 5S7, Canada

2 Department of Biology, Mount Allison University, Sackville, NB, Canada

3 Département de Biologie, Université de Moncton, Moncton, NB, Canada

4 CCMAR, Centro de Ciências do Mar do Algarve, Campus de Gambelas, Universidade do Algarve, Faro, Portugal de novo glucose synthesis (gluconeogenesis), important for glucose homeostasis, likely is restricted to the digestive gland, contrary to previous reports of widespread gluconeogenesis among cephalopod tissues. Short-term starvation (3-5 days) had few effects on enzymatic capacities. Similar to vertebrates, lipid-based fuels, putatively mobilized from fat stores in the digestive gland, appear to be important energy sources for cephalopods, especially during starvation when glycolytic capacity is decreased perhaps to conserve available glucose.

Keywords Cephalopod $\cdot$ Energy metabolism $\cdot$ Metabolic fuel preference $\cdot$ Enzyme activity $\cdot$ Starvation $\cdot$ Fasting . Lipid · Ketone body · Amino acid · Glucose · Glycolysis · Gluconeogenesis · Digestive gland

\section{Introduction}

Cephalopods are diverse and abundant molluscs that show functional convergence with fishes yet also differ in important ways extending from whole-animal locomotion to metabolic fuel preferences, possibly as a consequence of phylogenetic and life history constraints (O'Dor and Webber 1986). For example, whereas lipids are a key metabolic fuel in bony fishes (and most other vertebrates), the general consensus has been that cephalopods, like other molluscs, have a poor capacity to metabolize these high-energy nutrients (Storey and Storey 1983; O'Dor and Webber 1986; Hochachka 1995; Lee 1995). Cephalopods show relatively slow in vivo catabolism of lipids (O'Dor et al. 1984), have comparatively low tissue activities of the fatty acid catabolic enzyme 3-hydroxyacyl CoA dehydrogenase (HOAD) (Mommsen et al. 1981; Ballantyne et al. 1981; Mommsen and Hochachka 1981; Driedzic et al. 1990), and have 
systemic hearts with negligible mitochondrial oxidation of fatty acids or activity of carnitine palmitoyltransferase (CPT), a key enzyme of mitochondrial fatty acid oxidation (Ballantyne et al. 1981; Mommsen and Hochachka 1981; Driedzic et al. 1990; Agnisola et al. 1991). Instead, cephalopod energy metabolism is thought to be fueled heavily by protein, as well as carbohydrate in particular to sustain exercise (Storey and Storey 1983; Lee 1995; Hochachka 1995). Yet, many cephalopods accumulate a large lipid store in their digestive gland (Lee 1995; Rosa et al. 2005), a voluminous organ analogous to the vertebrate liver, and the possibility of tissue-specific variation in activity of CPT, arguably the best enzymatic indicator of capacity for fatty acid oxidation, is largely unexplored.

The responses of cephalopods to starvation, in particular, suggest that their use of lipid fuels perhaps has been underestimated. Food limitation is a common challenge for animals and responses to starvation provide valuable insight into metabolic organization and strategies for coping with energy stress (McCue 2010; Secor and Carey 2016). In general, cephalopods are sensitive to starvation because their "live-fast, die-young" life history, which involves a high metabolic rate and fast growth, necessitates frequent food consumption (O'Dor and Webber 1986). Yet, cephalopods can encounter starvation periods resulting from environmental stress or life history events (Wells and Clarke 1996; Seibel et al. 2000). When deprived of food, cephalopods initially mobilize lipids (e.g. triacylglycerols), which are typically stored in the digestive gland (BoucherRodoni and Mangold 1985; Castro et al. 1992; Lee 1995; Lamarre et al. 2012; Morillo-Velarde et al. 2013) and appear to be used as metabolic fuel based on increased $\mathrm{CO}_{2}$ production from radiolabelled fatty acid in starved octopus (O'Dor et al. 1984). As starvation extends to 5-10+ days, triacylglycerol stores become depleted, body protein is increasingly called upon as a metabolic fuel, and metabolic rate is lowered (Boucher-Rodoni and Mangold 1985; Castro et al. 1992; Grigoriou and Richardson 2009; Lamarre et al. 2012). The shift to lipid mobilization and eventually to protein mobilization appears broadly similar to the metabolic starvation response in vertebrates (Cahill 2006; Bar 2014; Secor and Carey 2016), but the apparent reliance upon lipid during starvation in cephalopods is paradoxical given the current view of their poor capacity for fatty acid oxidation. Indeed, there are conflicting opinions about whether digestive gland lipids represent an energy store or an excretory product (Castro et al. 1992; Wells and Clarke 1996; Semmens 1998; Seibel et al. 2000; Moltschaniwskyj and Johnston 2006). Two potential, yet unexplored, explanations for the apparent reliance upon lipids during food deprivation are that starvation induces a greater capacity for fatty acid oxidation or that stored lipid could be mobilized as ketone bodies. A characteristic starvation response in mammals involves the hepatic conversion of fatty acids to ketone bodies, which are released into the blood to fuel metabolism in certain extrahepatic tissues (e.g. heart, brain) (Gibson and Harris 2002). The capacity of cephalopods to exploit ketone bodies as fuel during starvation is unknown, but tissues of one squid species showed activity of a key enzyme (succinyl coenzyme-A ketotransferase, SKT) involved in ketone body oxidation (Ballantyne et al. 1981).

Little is known about the importance of carbohydrates as metabolic fuels in starved cephalopods. Based on radiolabel studies on starved octopus, O'Dor et al. (1984) suggested that available glucose is quickly depleted (within 1 day), while the large glycogen stores in the mantle are untouched and reserved for burst exercise even after 5 days of starvation. In starving mammals and fishes, glucose use typically is downregulated in non-essential tissues such as muscle while glycogen stores are mobilized to sustain glucose supply to specific tissues such as brain; as these stores are depleted, gluconeogenesis is increasingly relied upon to produce glucose in the liver from amino acids sourced from degradation of body protein (Gibson and Harris 2002; Bar and Volkoff 2012). Gluconeogenesis, a key metabolic pathway involved in regulation of circulating glucose levels, is of unknown importance in starved cephalopods. Interestingly, a limited number of available studies suggest that, unlike vertebrates, gluconeogenesis in cephalopods is not limited to the digestive gland (i.e. "liver"), based on activities of gluconeogenic enzymes and incorporation of radiolabelled amino acids into the glycogen pools in several tissues (although the terminal enzyme required for de novo glucose synthesis, glucose- 6 phosphatase, has not been measured in cephalopod tissues) (Ballantyne et al. 1981; Fields and Hochachka 1982; Hochachka and Fields 1982). Gluconeogenesis therefore could be an important process during starvation in cephalopods.

We undertook a comprehensive survey of enzymatic capacities of tissue metabolism in fed and starved common cuttlefish (Sepia officinalis) to elucidate the metabolic organization of cephalopods and the metabolic response that underlies survival of starvation. Profiles of maximal activities of metabolic enzymes provide a robust indicator of metabolic capacities and fuel preferences among animals (Newsholme and Crabtree 1986; Suarez 2012). Cuttlefish and certain other cephalopods are important food species whose nutrition and starvation responses are particularly relevant given the increasing interest in their culture (Navarro et al. 2014; Sykes et al. 2014). To clarify the paradox of lipid mobilization during starvation in cephalopods, we measured the enzymatic capacities of cuttlefish tissues to use fatty acids and ketone bodies as metabolic fuels and examined for the first time whether these capacities are modulated by starvation. We hypothesized that the capacities to use lipid-based fuels would be more widespread 
than previously recognized and enhanced during starvation. We also examined how starvation modulated enzymatic capacities of the glycolytic pathway, hypothesizing a downregulation in line with a shift towards lipid-based fuels. Finally, we evaluated the notion that gluconeogenic capacity extends to tissues beyond the digestive gland in cephalopods and examined how starvation affects this capacity as well as key enzymes of biosynthetic pathways linked to glucose metabolism (pentose phosphate shunt and lipid biosynthesis).

\section{Materials and methods}

\section{Animals}

Common cuttlefish (S. officinalis) were obtained from a captive reared population at the Ramalhete Aquaculture Station (Ria Formosa, southern Portugal- $37^{\circ} 00^{\prime} 22.39^{\prime \prime} \mathrm{N}$; $7^{\circ} 58^{\prime} 02.69^{\prime \prime} \mathrm{W}$ ), according to the methods described by Sykes et al. (2014). The cuttlefish derived from eggs laid by a F3 captive stock. Cuttlefish were kept in large outdoor 5001 plastic tanks supplied with aerated, flow-through seawater $\left(21.0 \pm 2.1{ }^{\circ} \mathrm{C}\right.$; salinity $36.3 \pm 0.9 \mathrm{~g} \mathrm{l}^{-1}$; dissolved oxygen level was $94.8 \pm 4.6 \%$ air saturation) and were fed ad libitum daily with live grass shrimp (Palaemonetes varians). All experiments were conducted following Portuguese animal care guidelines.

\section{Starvation protocol}

Experiments were carried out at the Ramalhete Aquaculture Station in May 2014. Cuttlefish were housed individually in floating baskets (5.5 1 water volume; $31 \mathrm{~cm} \times 22 \mathrm{~cm} \times 8 \mathrm{~cm}$ ) with $1 \mathrm{~mm}$ mesh size, placed within four larger plastic holding tanks (500 l) that were outdoors and covered with netting, following standards for good welfare (Fiorito et al. 2015). The cuttlefish were fed daily and allowed to acclimate to these conditions for a week before experimentation. Individual cuttlefish were randomly selected to be subjected to one of three treatments: fed daily ( $\mathrm{Fed} ; n=8$; mass at sampling $43.9 \pm 5.3 \mathrm{~g}$ ), starved for 3-5 days (Short-starved; $n=7$; $37.7 \pm 1.3 \mathrm{~g}$ ), or starved for 12 days (Long-starved; $n=8$; $30 \pm 0.8 \mathrm{~g}$ ). The masses of fed and short-starved individuals were statistically similar, but long-starved individuals weighed significantly less (one-way ANOVA with Newman-Keuls post-test, $p<0.05$ ), consistent with previous results for starved cuttlefish (Castro et al. 1992). Following the treatments, cuttlefish were killed by anaesthesia in seawater with $5 \%$ ethanol, followed by bisection of the brain and severing of the ventral nerve and optical lobes. Hemolymph was withdrawn from the cephalic vein using a $25 \mathrm{G}$ needle. Systemic heart, branchial hearts, gill, ventral mantle muscle, and digestive gland were excised and frozen on dry ice and stored at $-80^{\circ} \mathrm{C}$ until analysis.

\section{Triacylglycerol and ketone body assays}

Triacylglycerol content of the digestive gland was measured as described by Lamarre et al. (2012). We attempted to measure two ketone bodies, acetoacetate and $\beta$-hydroxybutyrate, in acidified (6\% perchloric acid) and then neutralized ( $3 \mathrm{M} \mathrm{K}_{2} \mathrm{CO}_{3}$ ) extracts of hemolymph using well-established end-point or kinetic methods (McMurray et al. 1984). We discovered that these methods were unsuitable for cuttlefish because of substantial background rates of redox reactions in hemolymph, possibly due to an abundance of metal ions, which result in erroneously high measurements. Addition of up to $5 \mathrm{mM}$ EDTA to the assay buffer did not improve assay resolution, whereas this has been shown to be effective in other pyridine nucleotidelinked metabolite assays (Storey et al. 1979).

\section{Enzyme assays}

Frozen tissues were weighed and homogenized in ten volumes of ice-cold homogenization buffer using a Polytron homogenizer. The homogenization buffer contained $50 \mathrm{mM}$ imidazole (pH 7.4 at $22{ }^{\circ} \mathrm{C}$ ), $1 \mathrm{mM}$ disodium EDTA, and $40 \mu \mathrm{l} / \mathrm{ml}$ (digestive gland) or $20 \mu \mathrm{l} / \mathrm{ml}$ (all other tissues) of protease inhibitor (Sigma P2714; used 10× concentrate, i.e. bottle contents reconstituted in $10 \mathrm{ml}$ ). Homogenates were centrifuged at $4{ }^{\circ} \mathrm{C}$ and $1000 \times g$ for 10 min (mantle) or $600 \times g$ for $5 \mathrm{~min}$ (all other tissues) and dilutions of the supernatant were used for the enzyme assays. Enzyme measurements were made for all sampled tissues from fed, short-starved, and long-starved individuals, with the following exceptions. First, the only enzymes assayed for branchial heart were glycolytic (HK, PFK, PK) and gluconeogenic (PEPCK, FBPase, G6Pase). Second, short-starved cuttlefish were not assayed for: PFK, PK, branchial heart $\mathrm{HK}$, and all gluconeogenic enzymes except digestive gland G6Pase. These exclusions were done for logistical reasons and because, regarding exceptions of short-starved cuttlefish, there were few differences from fed controls even after long-starvation.

Maximal enzyme activities were measured at $28 \pm 0.1{ }^{\circ} \mathrm{C}$ using a SpectraMax M5 microplate spectrophotometer (Molecular Devices, Sunnyvale, CA, USA). Activities of most enzymes were ascertained by measuring the oxidation or reduction of pyridine nucleotides at $340 \mathrm{~nm}$ (millimolar extinction coefficient $\varepsilon_{340}$, $6.22 \mathrm{mM}^{-1} \mathrm{~cm}^{-1}$ ). Citrate synthase (CS) and carnitine palmitoyltransferase (CPT) activities were monitored at $412 \mathrm{~nm}$ by following the reaction of liberated free 
CoA with 5,5'-dithiobis 2-nitrobenzoic acid (DTNB) $\left(\varepsilon_{412}, 13.6 \mathrm{mM}^{-1} \mathrm{~cm}^{-1}\right)$. Note, as freeze-thaw of tissues can inactivate CPT-1 (Pande et al. 1990), our measurements of CPT may largely reflect activity of CPT-2, which together with CPT-1 facilitates entry of long-chain fatty acids into the mitochondria. Succinyl coenzyme-A ketotransferase (SKT) activity was measured by following the disappearance of acetoacetyl CoA at $310 \mathrm{~nm}\left(\varepsilon_{310}\right.$, $11.9 \mathrm{mM}^{-1} \mathrm{~cm}^{-1}$ ). The optical pathlength was calculated for a final microplate well volume of $200 \mu$ l following the method of Brooks (1994). Assay conditions followed established protocols for mollusc or cephalopod tissues (Ballantyne et al. 1981; Hochachka and Fields 1982; Mommsen et al. 1983; Driedzic et al. 1990; Stuart and Ballantyne 1996). The glucose-6-phosphatase (G6Pase) assay was modified from the methods described by Stio et al. (1988) and Alegre et al. (1988). For NADH-linked assays, $\mathrm{KCN}$ was added to inhibit endogenous oxidation of NADH by NADH dehydrogenase (Sidell et al. 1987). Our preliminary measurements confirmed that reaction rates were linear with time and proportional to the amount of homogenate added for all enzymes. Enzyme activities were measured in duplicate with paired simultaneous, separate control reactions where substrate was omitted. Enzyme assay conditions were as follows:

\section{Enzymes of ketone body metabolism}

Succinyl coenzyme-A ketotransferase, SKT (E.C. 2.8.3.5): $50 \mathrm{mM}$ imidazole buffer ( $\mathrm{pH} 8.0$ ), $5 \mathrm{mM} \mathrm{MgCl}_{2}, 0.11 \mathrm{mM}$ acetoacetyl CoA, $1 \mathrm{mM}$ succinate (omitted for control).

$D / L-\beta$-hydroxybutyrate dehydrogenase, $\mathrm{D} / \mathrm{L}-\beta-\mathrm{HBDH}$ (E.C. 1.1.1.30): $50 \mathrm{mM}$ imidazole buffer ( $\mathrm{pH} 8.0), 1 \mathrm{mM}$ $\mathrm{KCN}, 11.25 \mathrm{mM} \mathrm{NAD}{ }^{+}, 2 \mathrm{mM}$ DTT, $25 \mathrm{mM} \mathrm{D} / \mathrm{L}-\beta-$ hydroxybutyrate (omitted for control).

\section{Enzymes of lipid oxidation}

Carnitine palmitoyltransferase, CPT (E.C. 2.3.1.21): $50 \mathrm{mM}$ imidazole buffer ( $\mathrm{pH} 8.0$ ), $0.2 \mathrm{mM}$ DTNB, $0.1 \mathrm{mM}$ palmitoyl CoA, $5 \mathrm{mM}$ L-carnitine (omitted for control).

3-Hydroxyacyl CoA dehydrogenase, HOAD (E.C.

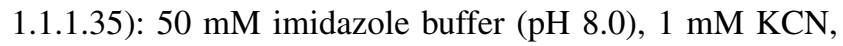
$0.1 \mathrm{mM} \mathrm{NADH}, 0.1 \mathrm{mM}$ acetoacetyl CoA (omitted for control).

\section{Enzymes of glycolysis and anaerobic glycolysis}

Hexokinase, HK (E.C. 2.7.1.1): $50 \mathrm{mM}$ imidazole buffer (pH 7.4), $5 \mathrm{mM} \mathrm{MgCl} 2,1 \mathrm{mM}$ glucose, $0.4 \mathrm{mM} \mathrm{NADP}^{+}$, $2 \mathrm{U} / \mathrm{ml}$ glucose 6 phosphate dehydrogenase, $2 \mathrm{mM}$ ATP (omitted for control).
Phosphofructokinase, PFK (E.C. 2.7.1.11): $50 \mathrm{mM}$ imidazole buffer ( $\mathrm{pH} 7.4$ ), $1 \mathrm{mM} \mathrm{KCN}, 10 \mathrm{mM} \mathrm{MgCl}{ }_{2}$, $50 \mathrm{mM} \mathrm{KCl}, 1 \mathrm{mM}$ ATP, $0.2 \mathrm{mM}$ NADH, $3 \mathrm{mM}$ AMP, $1 \mathrm{U} / \mathrm{ml}$ glycerol-3-phosphate dehydrogenase, $5 \mathrm{U} / \mathrm{ml}$ triosephosphate isomerase, $1 \mathrm{U} / \mathrm{ml}$ aldolase, $8 \mathrm{mM}$ fructose6-phosphate (omitted for control).

Pyruvate kinase, PK (E.C. 2.7.1.40): $50 \mathrm{mM}$ imidazole buffer (pH 7.4), $1 \mathrm{mM} \mathrm{KCN}, 10 \mathrm{mM} \mathrm{MgCl} 2,50 \mathrm{mM} \mathrm{KCl}$, $5 \mathrm{mM}$ ADP, $0.15 \mathrm{mM}$ NADH, $5 \mathrm{U} / \mathrm{ml}$ lactate dehydrogenase, $5 \mathrm{mM}$ PEP (omitted for control).

Octopine dehydrogenase, ODH (E.C. 1.5.1.11): $50 \mathrm{mM}$ imidazole buffer ( $\mathrm{pH} 7.4$ ), $1 \mathrm{mM} \mathrm{KCN}, 0.2 \mathrm{mM} \mathrm{NADH}$, $4 \mathrm{mM}$ pyruvate, $10 \mathrm{mM}$ arginine (omitted for control).

\section{Enzymes of gluconeogenesis}

Glucose-6-phosphatase, G6Pase (E.C. 3.1.3.9): $50 \mathrm{mM}$ imidazole buffer ( $\mathrm{pH} 7.4$ ), $2 \mathrm{mM}$ NAD, $9.6 \mathrm{U} / \mathrm{ml}$ glucose dehydrogenase, $0.7 \mathrm{U} / \mathrm{ml}$ mutarotase, $20 \mathrm{mM}$ glucose6-phosphate (omitted for control).

Fructose 1,6-bisphosphatase, FBPase (E.C. 3.1.3.11): $50 \mathrm{mM}$ imidazole buffer ( $\mathrm{pH} 7.4), 15 \mathrm{mM} \mathrm{MgCl}_{2}, 0.2 \mathrm{mM}$ $\mathrm{NADP}^{+}, 2 \mathrm{U} / \mathrm{ml}$ glucose-6-phosphate dehydrogenase, $10 \mathrm{U} / \mathrm{ml}$ phosphoglucose isomerase, $0.2 \mathrm{mM}$ fructose 1,6-bisphosphate (omitted for control).

Phosphoenolpyruvate carboxykinase, PEPCK (E.C. 4.1.1.32): $50 \mathrm{mM}$ imidazole buffer ( $\mathrm{pH} 7.4), 1 \mathrm{mM} \mathrm{KCN}$, $1 \mathrm{mM} \mathrm{MnCl} 2,1 \mathrm{mM} \mathrm{MgCl}{ }_{2}, 0.17 \mathrm{mM}$ NADH, $1.1 \mathrm{mM}$ PEP, $19 \mathrm{U} / \mathrm{ml}$ malate dehydrogenase, $1.5 \mathrm{mM}$ IDP, $20 \mathrm{mM}$ $\mathrm{NaHCO}_{3}$ (omitted for control).

Enzyme of the pentose phosphate pathway

Glucose 6-phosphate dehydrogenase, G6PDH (E.C. 1.1.1.49): $50 \mathrm{mM}$ imidazole buffer ( $\mathrm{pH} 7.4$ ), $7 \mathrm{mM} \mathrm{MgCl}{ }_{2}$, $0.4 \mathrm{mM} \mathrm{NADP}^{+}, 1 \mathrm{mM}$ glucose 6-phosphate (omitted for control).

\section{Enzyme of lipid biosynthesis}

Glycerol 3-phosphate dehydrogenase, G3PDH (E.C. 1.1.1.8): $50 \mathrm{mM}$ imidazole buffer ( $\mathrm{pH} 7.4$ ), $1 \mathrm{mM} \mathrm{KCN}$, $0.15 \mathrm{mM}$ NADH, $2 \mathrm{mM}$ dihydroxyacetone phosphate (omitted for control).

\section{Enzyme of amino acid metabolism}

Aspartate aminotransferase, AspAT (E.C. 2.6.1.1): $50 \mathrm{mM}$ imidazole buffer ( $\mathrm{pH} 7.4$ ), $0.025 \mathrm{mM}$ pyridoxal phosphate, $1 \mathrm{mM}$ KCN, $0.2 \mathrm{mM}$ NADH, $8 \mathrm{U} / \mathrm{ml}$ malate dehydrogenase, $40 \mathrm{mM}$ aspartate, $10 \mathrm{mM} \alpha$-ketoglutarate (omitted for control). 
Enzyme of citric acid cycle

Citrate synthase, CS (E.C. 4.1.3.7): $50 \mathrm{mM}$ imidazole buffer ( $\mathrm{pH} 8.0$ ), $0.3 \mathrm{mM}$ acetyl CoA, $0.1 \mathrm{mM}$ DTNB, $0.5 \mathrm{mM}$ oxaloacetate (omitted for control).

Activities are presented as $\mu \mathrm{mol}$ substrate converted to product per minute per gram of wet tissue

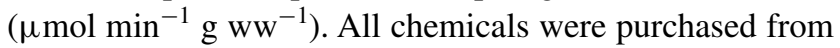
Sigma Chemical Co. (St. Louis, MO, USA), except mutarotase, which was purchased from Calzyme Laboratories Inc. (San Luis Obispo, CA, USA).

\section{Statistics}

All data are presented as mean \pm SEM. Comparisons of enzyme activities were made using two-way ANOVA with Bonferroni post hoc tests and tissue and feeding state as factors. For HK and G6Pase, short-starved data were unavailable for branchial heart, so the branchial heart data were analyzed separately using a Student's $t$ test to assess the effect of starvation. Digestive gland triacylglycerol levels were compared across feeding states using one-way ANOVA with Bonferroni post hoc test. Data were log or square root transformed, if necessary, to meet assumptions of equal variance and normality. All analyses were carried out with Prism 5.0b (GraphPad, La Jolla, CA, USA). The level of statistical significance was taken as $p<0.05$.

\section{Results}

\section{Triacylglycerol levels in digestive gland}

Triacylglycerol reserves in the digestive gland decreased by $72 \%$ within $3-5$ days of starvation, and were almost completely depleted by 12 days of starvation (one-way ANOVA, $p<0.05$ ) (Fig. 1).

\section{Enzymatic capacities for lipid and ketone body metabolism}

CPT activity was not detectable in systemic heart (Fig. 2a). High apparent levels of deacylase activity obscured measurement of CPT in digestive gland. Mantle had very low levels of CPT activity, which were maintained during shortstarvation (two-way ANOVA, $p>0.05$ ) but decreased by $82 \%$ after long-starvation (two-way ANOVA, $p<0.01$ ). Gill had readily detectable, albeit low, levels of CPT that were greater than mantle CPT activities (two-way ANOVA, $p<0.0001$ ) and were unaffected by starvation (two-way ANOVA, $p>0.05$ ).

HOAD activity was detectable in all tissues, at generally higher levels than CPT, and with the lowest levels in mantle

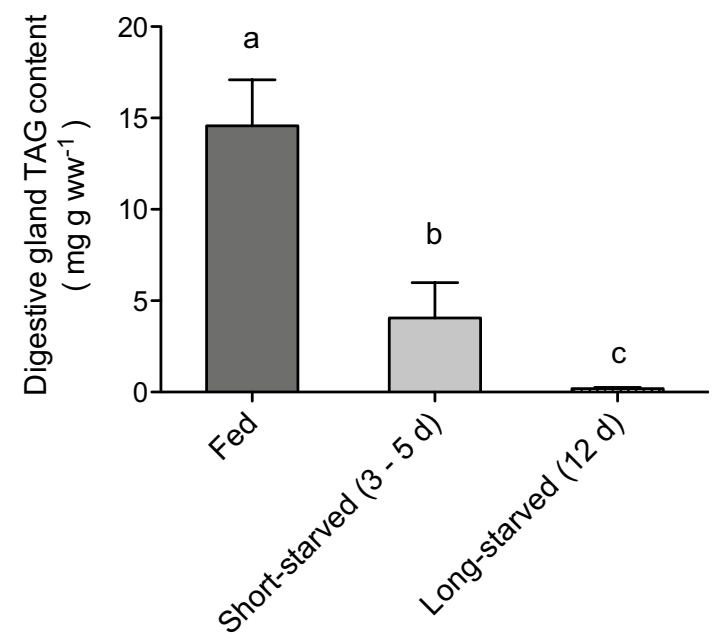

Fig. 1 Triacylglycerol (TAG) content in digestive gland from cuttlefish fed daily or starved for 3-5 or 12 days. Values with different letters are significantly different (one-way ANOVA with Bonferroni, $p<0.05)$. Data are mean \pm SEM, $n=7-8$. These data were previously published in Lamarre et al. (2016)

and the highest levels in digestive gland and systemic heart (two-way ANOVA, $p<0.0001$ ) (Fig. 2b). HOAD activity was unaffected by starvation in mantle and gill (two-way ANOVA, $p>0.05$ ). However, in digestive gland and systemic heart, short-starvation was associated with a 35 and $50 \%$ increase in HOAD activity compared with fed individuals, respectively (two-way ANOVA, $p<0.05$ ). This increase was tempered following long-starvation, declining to activities that were 16 and $30 \%$ above the values for fed individuals.

While D/L- $\beta-H B D H$ was not detected in any tissue (data not shown), SKT was readily detected in all tissues, with the lowest levels in mantle and the highest levels in digestive gland and systemic heart (two-way ANOVA, $p<0.0001$ ) (Fig. 2c). SKT activity remained unchanged in all tissues throughout the starvation period (two-way ANOVA, $p>0.05$ ).

\section{Enzymatic capacities for glycolysis and anaerobic glycolysis}

HK activity was highest in systemic heart and lowest in mantle and digestive gland (two-way ANOVA, $p<0.0001$ ) (Fig. 3a). HK activity was affected by starvation in all tissues. Mantle and gill showed gradual decreases with starvation duration, becoming significantly lower than fed controls following longstarvation (by 35 and $44 \%$, respectively) (two-way ANOVA, $p<0.05)$. In digestive gland, HK activity was rendered not detectable after only short-starvation. In systemic heart, HK activity was maintained at fed 

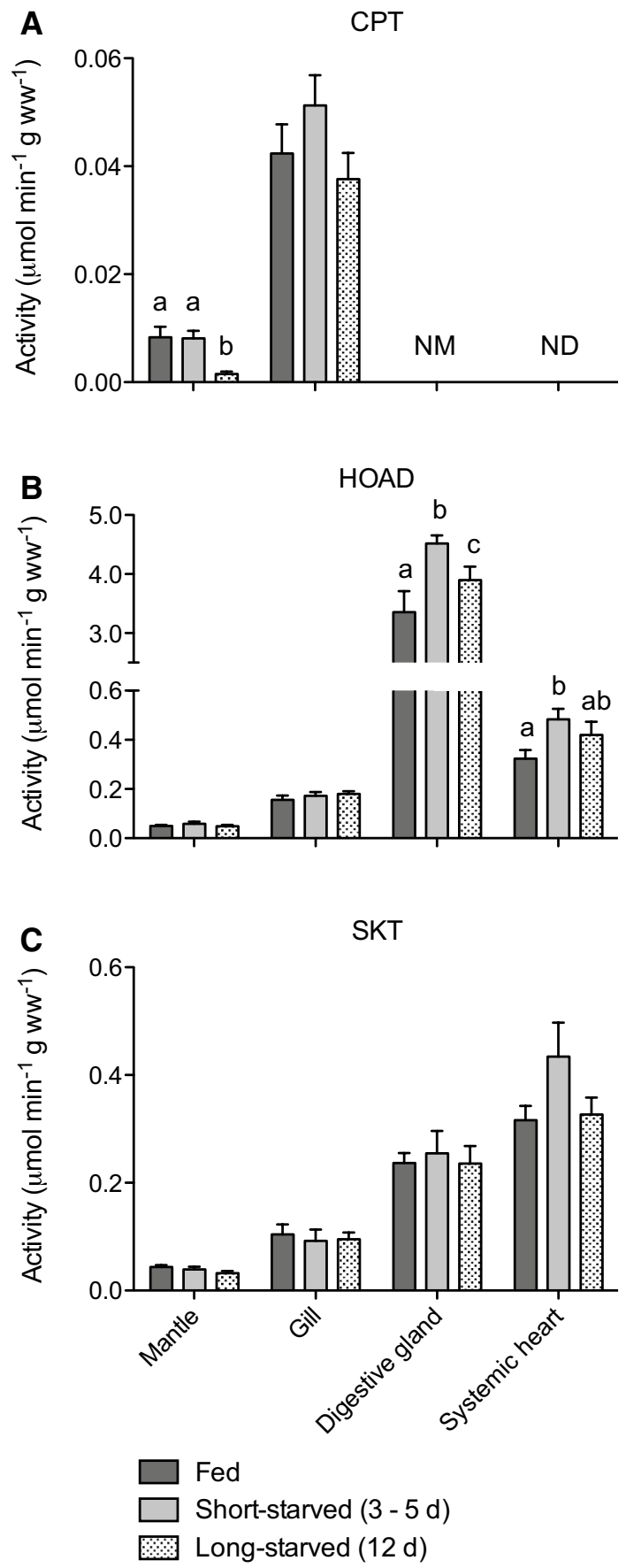

Fig. 2 Activities of enzymes of fatty acid oxidation (a carnitine palmitoyltransferase, CPT; b 3-hydroxyacyl CoA dehydrogenase, HOAD) and ketone body metabolism (c succinyl coenzyme-A ketotransferase, SKT) in tissues from cuttlefish fed daily or starved for 3-5 or 12 days. Note split $y$ axis for HOAD. Within each tissue, values with different letters are significantly different from each other (two-way ANOVA with Bonferroni, $p<0.05$ ) and an absence of letters indicate no significant difference between values. For clarity, statistical comparisons between tissues are not shown (see text for description of results). $N D$ not detectable, $N M$ not measured (see text). Data are mean \pm SEM. $n=7-8$, except for: CPT in short-starved mantle $(n=6)$; all enzymes in long-starved systemic heart $(n=4)$ levels following short-starvation (two-way ANOVA, $p>0.05$ ), but decreased by $28 \%$ following longstarvation (two-way ANOVA, $p<0.05$ ). HK activity in branchial heart was not measured in short-starved individuals, but following long-starvation levels were decreased by $21 \%$ compared with fed controls ( $t$ test, $p<0.01)$.

PFK activity was higher in mantle and systemic heart compared with the low values in other tissues (two-way ANOVA, $p<0.0001$ ) (Fig. 3b). PFK activities did not change significantly following long-starvation in any tissue except for mantle and systemic heart, where there was a 49 and $64 \%$ decrease in activity, respectively (two-way ANOVA, $p<0.05$ ).

PK activity was highest in mantle and lowest in gill and digestive gland (two-way ANOVA, $p<0.0001$ ) (Fig. 3c). PK activities were unchanged by starvation in all tissues except digestive gland, where long-starvation was associated with a $95 \%$ decrease in activity (two-way ANOVA, $p<0.05$ ).

ODH activity was much higher in mantle and systemic heart compared with gill or digestive gland (two-way ANOVA, $p<0.0001$ ) (Fig. 3d). ODH activity was unaffected by starvation in gill and systemic heart (two-way ANOVA, $p>0.05$ ). In mantle, ODH activity initially was unaffected by starvation but decreased by $37 \%$ following long-starvation (two-way ANOVA, $p<0.01$ ). In digestive gland, a decrease in ODH activity of $90 \%$ or more persisted throughout the starvation period (two-way ANOVA, $p<0.05)$.

\section{Enzymatic capacities for gluconeogenesis}

PEPCK activity in mantle and systemic heart was unchanged following long-starvation (two-way ANOVA, $p>0.05$ ) (Fig. 4a). PEPCK activity was not detected in gill, digestive gland, or branchial heart.

FBPase activity was found at relatively high levels in digestive gland, and at significantly lower levels in mantle, systemic heart, and branchial heart (two-way ANOVA, $p<0.0001$ ) (Fig. 4b). FBPase activity was not detected in gill. FBPase activities were not affected by long-starvation (two-way ANOVA, $p>0.05$ ).

G6Pase activity was present in digestive gland and at a lower level in branchial heart (two-way ANOVA, $p<0.0005$ ), but not found in mantle, gill, or systemic heart (Fig. 4c). Long-starvation had no effect on activity in branchial heart $(t$ test, $p>0.05$ ). In digestive gland, G6Pase activity was retained during short-starvation (twoway ANOVA, $p>0.05$ ) but decreased by $57 \%$ after longstarvation (two-way ANOVA, $p<0.001$ ). 

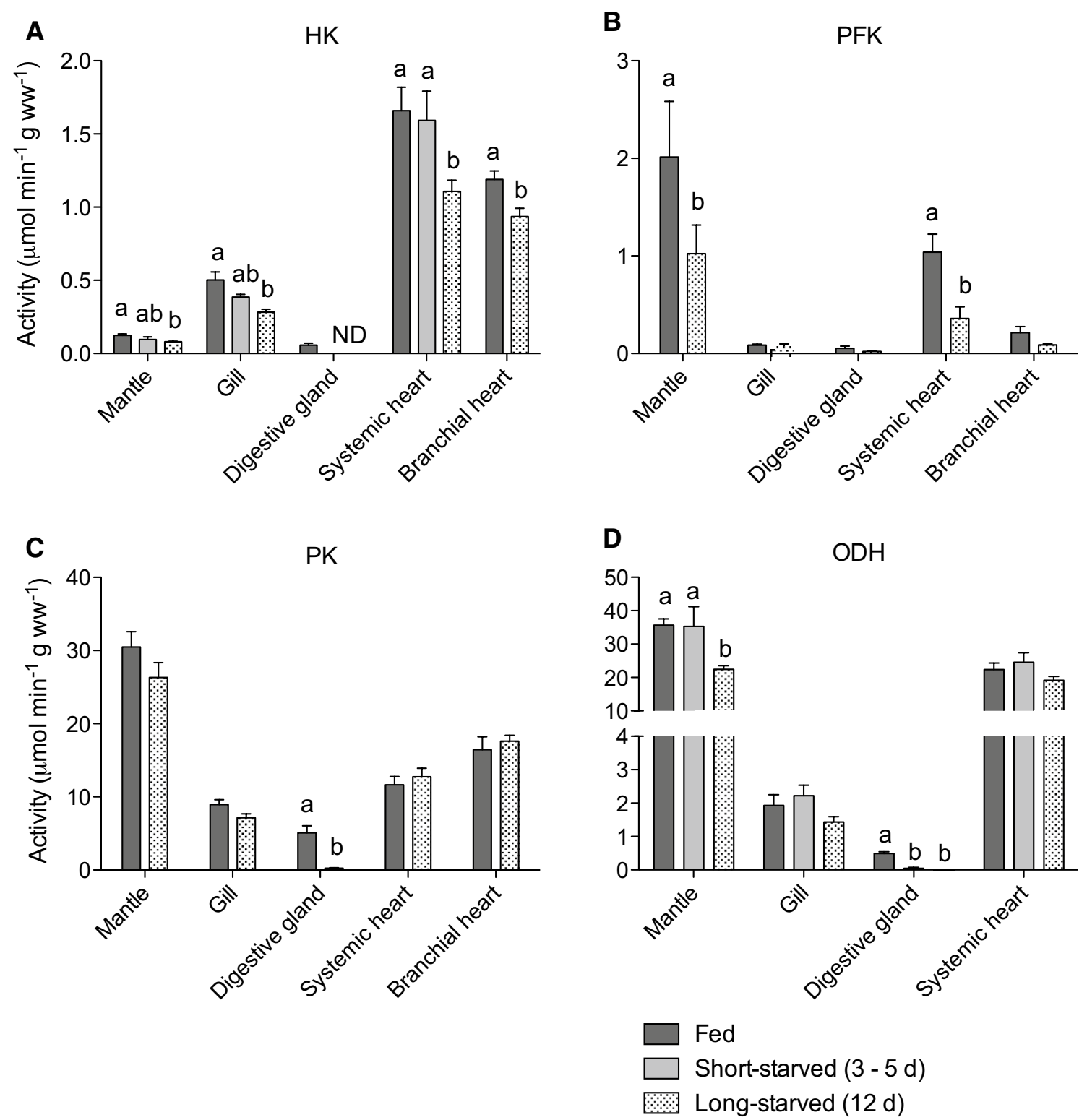

Fig. 3 Activities of enzymes of glycolysis (a hexokinase, HK; b phosphofructokinase, PFK; c pyruvate kinase, PK) and anaerobic glycolysis (d octopine dehydrogenase, ODH) in tissues from cuttlefish fed daily or starved for $3-5$ or 12 days. Note, due to limited sample, short-starved samples were run only for HK (excluding digestive gland and branchial heart) and ODH. Note split $y$ axis for $\mathrm{ODH}$. Within each tissue, values with different letters are signifi-

\section{Enzymatic capacities for lipid biosynthesis and pentose phosphate pathway}

Under fed conditions, G3PDH activity was highest in mantle and digestive gland and lowest in gill (two-way ANOVA, $p<0.0001$ ) (Fig. 5a). G3PDH activity remained unchanged in gill and systemic heart even after long-starvation (twoway ANOVA, $p>0.05$ ). In mantle, G3PDH activity was initially maintained during starvation, but declined modestly but significantly by $17 \%$ following long-starvation

cantly different from each other (two-way ANOVA with Bonferroni, $p<0.05)$ and an absence of letters indicate no significant difference between values. For clarity, statistical comparisons between tissues are not shown (see text for description of results). $N D$ not detectable. Data are mean \pm SEM. $n=7-8$, except for: HK in short-starved mantle and gill $(n=6), \mathrm{ODH}$ in long-starved systemic heart $(n=4)$

(two-way ANOVA, $p<0.05$ ). On the other hand, G3PDH activity in digestive gland plummeted by over $97 \%$ under both short- and long-starvation (two-way ANOVA, $p<0.001)$.

G6PDH activity was higher in gill and digestive gland compared with systemic heart or mantle (two-way ANOVA, $p<0.0001$ ) (Fig. 5b). G6PDH activity was unaffected by starvation in all tissues (two-way ANOVA, $p>0.05$ ) except digestive gland, where it decreased by $40-50 \%$ following short- and long-starvation (two-way ANOVA, $p<0.001$ ). 

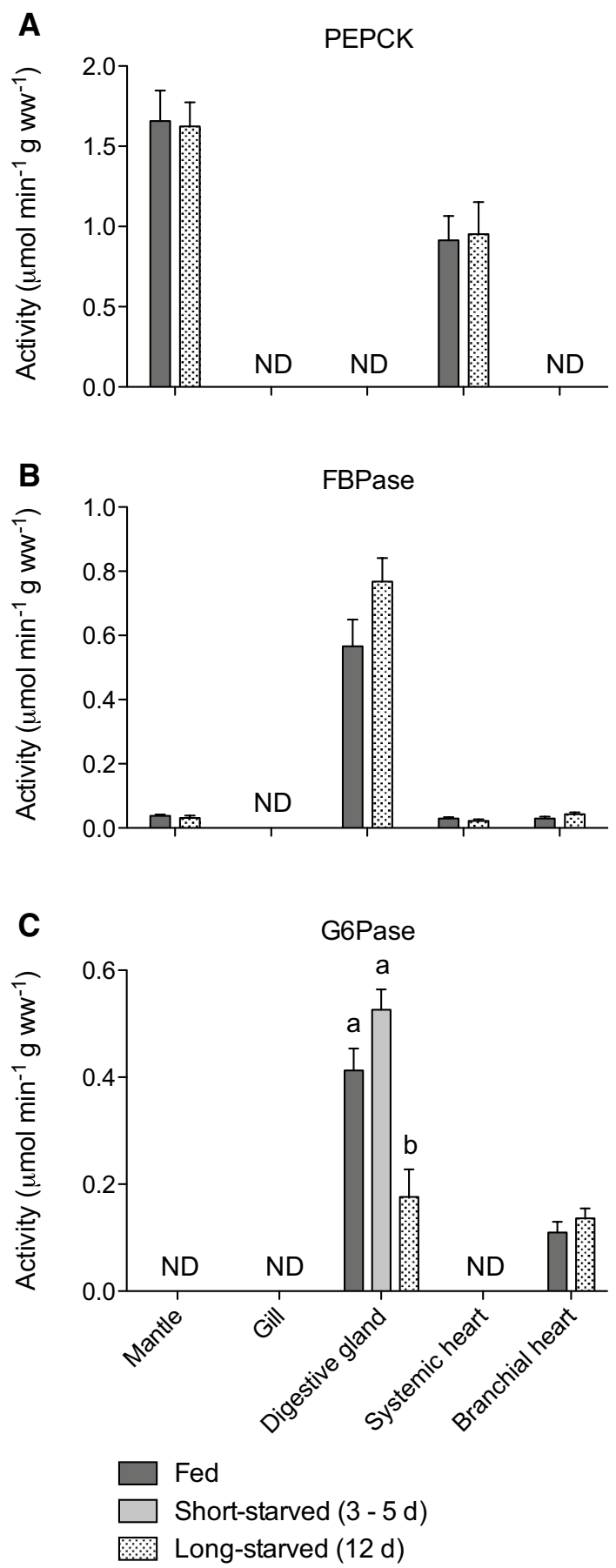

Fig. 4 Activities of enzymes of gluconeogenesis (a phosphoenolpyruvate carboxykinase, PEPCK; b fructose 1,6-bisphosphatase, FBPase; c glucose-6-phosphatase, G6Pase) in tissues from cuttlefish fed daily or starved for 3-5 or 12 days. Note, due to limited sample, short-starved samples were run only for G6Pase in digestive gland. Within each tissue, values with different letters are significantly different from each other (two-way ANOVA with Bonferroni, $p<0.05)$ and an absence of letters indicate no significant difference between values. For clarity, statistical comparisons between tissues are not shown (see text for description of results). $N D$ not detectable. Data are mean \pm SEM. $n=7-8$
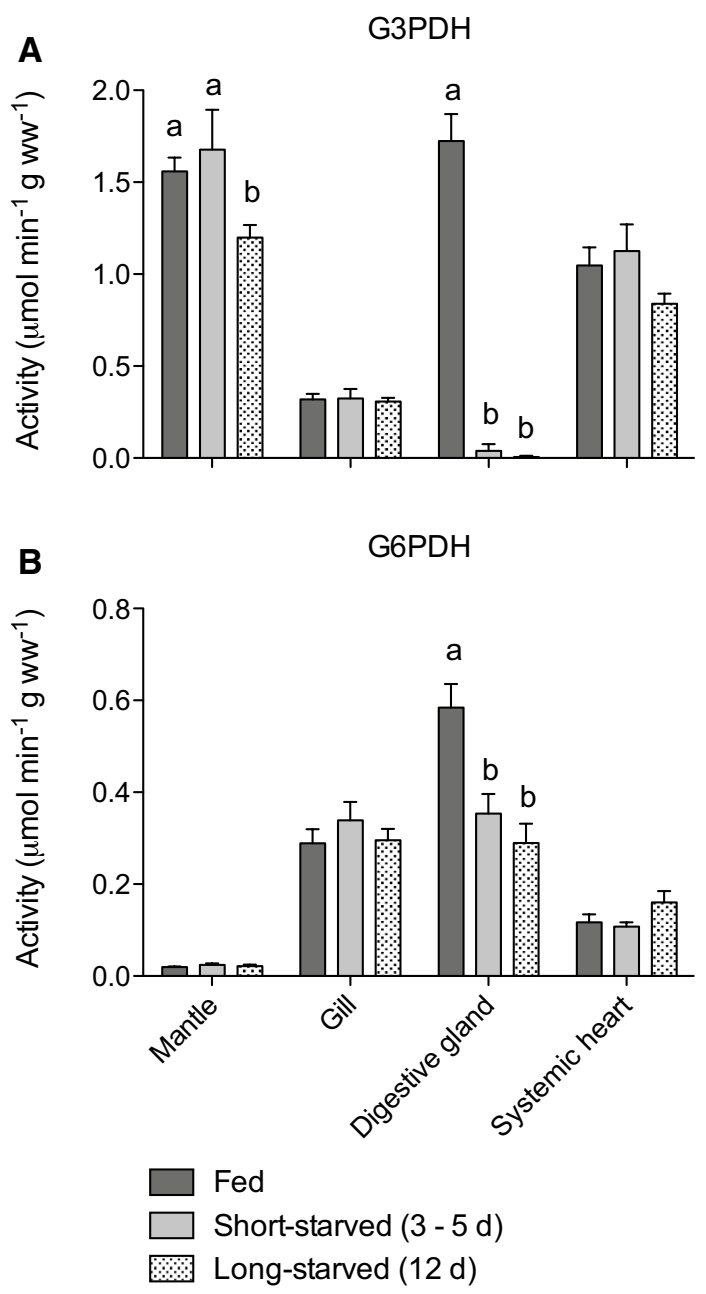

Fig. 5 Activities of enzymes related to lipid synthesis (a glycerol 3-phosphate dehydrogenase, G3PDH) and the pentose phosphate pathway (b glucose 6-phosphate dehydrogenase, G6PDH) in tissues from cuttlefish fed daily or starved for 3-5 or 12 days. Within each tissue, values with different letters are significantly different from each other (two-way ANOVA with Bonferroni, $p<0.05$ ) and an absence of letters indicate no significant difference between values. For clarity, statistical comparisons between tissues are not shown (see text for description of results). Data are mean \pm SEM. $n=7-8$, except for: short-starved gill $(n=6)$; long-starved systemic heart $(n=4)$

\section{Enzymatic capacities for amino acid metabolism}

AspAT was highly active in all tissues, but systemic heart had greater activity than the other tissues (two-way ANOVA, $p<0.0001$ ) (Fig. 6). AspAT activity was unaffected by starvation in mantle and gill (two-way ANOVA, $p>0.05$ ) but starvation was associated with a gradual and significant increase by up to $72 \%$ in digestive gland (two-way ANOVA, $p<0.01$ ). In systemic heart, there was a transient $25 \%$ significant increase in AspAT activity after short-starvation (two-way ANOVA, $p<0.001$ ) that returned to fed levels after long-starvation. 


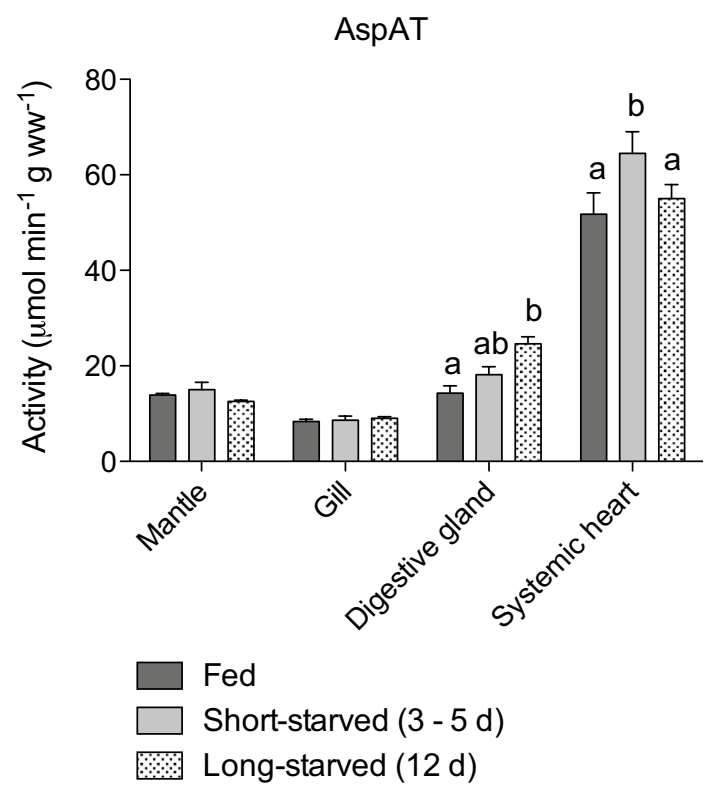

Fig. 6 Activities of aspartate aminotransferase (AspAT), an enzyme of amino acid metabolism, in tissues from cuttlefish fed daily or starved for 3-5 or 12 days. Within each tissue, values with different letters are significantly different from each other (two-way ANOVA with Bonferroni, $p<0.05$ ) and an absence of letters indicate no significant difference between values. For clarity, statistical comparisons between tissues are not shown (see text for description of results). Data are mean \pm SEM. $n=7-8$, except for: long-starved systemic heart $(n=4)$

\section{Enzymatic capacities for the citric acid cycle}

Systemic heart had much higher CS activity compared with other tissues (Fig. 7) (two-way ANOVA, $p<0.0001$ ). CS activity in gill and systemic heart was unaffected by starvation (two-way ANOVA, $p>0.05$ ), whereas long-starvation caused CS activity to decrease by $36 \%$ in mantle (two-way ANOVA, $p<0.05)$ and to become undetectable in digestive gland.

\section{Discussion}

As the first comprehensive investigation of how the enzymatic capacities of metabolic pathways are modulated by starvation in cephalopods, our study provides novel insight into the metabolic organization of these important molluscs and their strategies for coping with food limitation. The established notion that amino acids and carbohydrates are the preferred fuels in tissues of cephalopods (Storey and Storey 1983; Hochachka 1995; Lee 1995) is confirmed by the high activities of AspAT (Fig. 6) and well-developed glycolytic capacity in all tissues of cuttlefish (Fig. 3). However, lipid-based fuels, including fatty acids and the ketone body acetoacetate, appear to be more important as metabolic fuels in cephalopods than previously thought. Cuttlefish

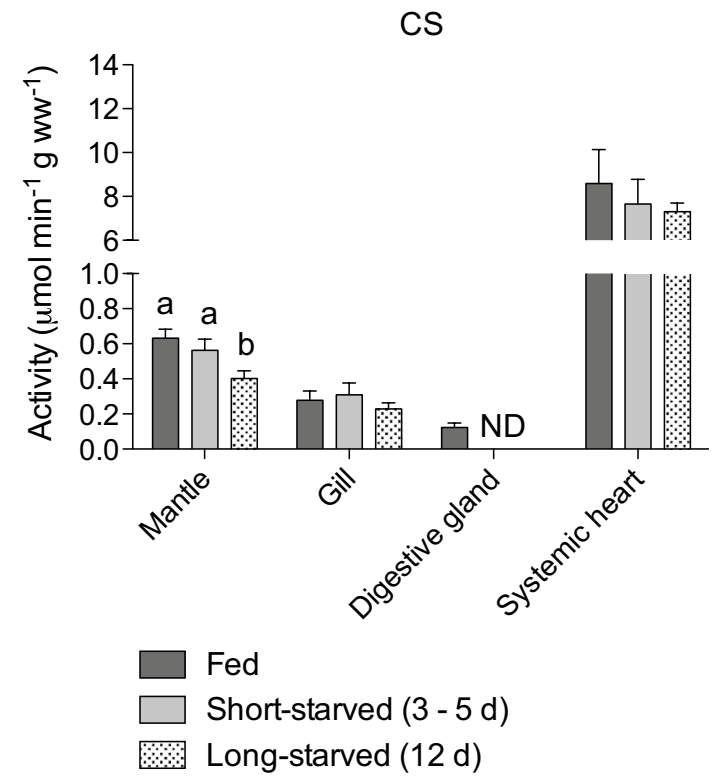

Fig. 7 Activities of citrate synthase (CS), an enzyme related to aerobic metabolism, in tissues from cuttlefish fed daily or starved for 3-5 or 12 days. Note split $y$ axis. Within each tissue, values with different letters are significantly different from each other (two-way ANOVA with Bonferroni, $p<0.05$ ) and an absence of letters indicate no significant difference between values. For clarity, statistical comparisons between tissues are not shown (see text for description of results). $N D$ not detectable. Data are mean \pm SEM. $n=7-8$, except for: longstarved systemic heart $(n=4)$

have a previously unrecognized, albeit low, capacity for fatty acid oxidation in gill, and even in mantle, and a widespread capacity to catabolize acetoacetate (Fig. 2), presumably produced from lipids in the digestive gland (Meyer et al. 1986; Stuart and Ballantyne 1996). Furthermore, the capacity to use lipid-based fuels is largely retained during starvation, while glycolytic capacity to use glucose as fuel is decreased (Figs. 2, 3). In starved cephalopods, lipid-based fuels appear to become more heavily relied upon while glucose is conserved, a response similar to that generally seen in starved vertebrates and which likely explains why starved cephalopods mobilize digestive gland lipids.

\section{Tissue-specific variation in capacity for fatty acid oxidation in cephalopods}

The CPT activities in cuttlefish tissues support the lack of mitochondrial fatty acid oxidation in systemic heart of cephalopods (Agnisola et al. 1991; Ballantyne et al. 1981; Mommsen and Hochachka 1981; Driedzic et al. 1990), yet indicate the novel presence of a capacity for fatty acid oxidation in gill and mantle. The demand for fatty acids as fuel in gill and mantle may be proportionally more significant than suggested by their relatively low CPT activities, 
because gill and mantle are large tissues in cephalopods ( $\sim 2$ and $\sim 30-40 \%$ of body mass in cuttlefish, respectively, vs. $\sim 0.1 \%$ for systemic heart; present authors, unpublished data; Gabr et al. 1999). The tissue-specific activities of CPT in cephalopods probably reflects phylogeny, because other marine molluscs have gills with mitochondria that oxidize fatty acids, gills and mantle with low but detectable CPT activities, and hearts without CPT or mitochondrial fatty acid oxidation (Ballantyne and Storey 1983; Ballantyne and Moyes 1987; Ballantyne and Berges 1991; Stewart et al. 1992). Our inability to accurately measure CPT in digestive gland matches previous failed attempts in molluscs, attributed to interference from deacylases in raw homogenates (Ballantyne et al. 1981; Stuart and Ballantyne 1996). However, fatty acid oxidation likely is important in cephalopod digestive gland given the very high HOAD activities, and high rates of mitochondrial fatty acid oxidation in digestive gland mitochondria of bivalves (Ballantyne and Storey 1984; Ballantyne and Moon 1985).

Unlike CPT, HOAD is widely distributed across cuttlefish tissues, albeit at low activities compared with bony fishes. The presence of appreciable HOAD activity in systemic heart, despite absence of CPT, is similar to other cephalopods (Ballantyne et al. 1981; Mommsen and Hochachka 1981; Mommsen et al. 1981; Driedzic et al. 1990) and also to muscles of chondrichthyan fishes (Speers-Roesch and Treberg 2010). Speculatively, in these cases, HOAD could be involved in short-chain fatty acid oxidation or peroxisomal $\beta$-fatty acid oxidation (Stewart et al. 1992; Islinger et al. 2010).

\section{Ketone body metabolism: Widespread capacity to use acetoacetate in cuttlefish tissues}

SKT activity was widely detected in cuttlefish tissues, whereas $\beta$-HBDH activity was absent, as observed in squid (Ballantyne et al. 1981) and other marine molluscs (Beis et al. 1980; Ballantyne and Moyes 1987; Ballantyne and Berges 1991; Stuart and Ballantyne 1996). Systemic hearts have the highest SKT activities in the cephalopods, suggesting that acetoacetate replaces fatty acids as a lipidbased fuel in this tissue. Unlike mammals, where SKT is exclusively for ketone body oxidation and thus is negligible in liver, molluscs, including cuttlefish (Fig. 2), have high SKT activity in the digestive gland, where it is thought to participate in ketogenesis (Zammit et al. 1979; Meyer et al. 1986; Stuart and Ballantyne 1996). Thus, the ketone body acetoacetate, but not $\beta$-HB, may be a useful metabolic fuel in cephalopods, similar to other marine molluscs where significant mitochondrial oxidation of acetoacetate also has been observed (Ballantyne and Moyes 1987).

Unfortunately, circulating acetoacetate was unresolvable in cuttlefish, because we discovered that available enzyme-linked spectrophotometric methods are unsuitable for use with cuttlefish hemolymph and GC-MS methods were unavailable to us. However, we made preliminary measurements of $\beta$-HB in cuttlefish hemolymph using a GC-MS method (Lamarre et al. 2014), finding that the peak corresponding to $\beta$-HB was not detected in cuttlefish hemolymph, whereas it was detected in a hemolymph sample spiked with commercial $\beta$-HB (present authors, unpublished observation). This result agrees with the absence of $\beta$-HBDH activity and the lack of circulating $\beta$-HB in other marine molluscs (Stewart et al. 1992).

\section{Glycolysis, tissue-specific fuel preferences, and the aerobic/anaerobic design of cephalopod tissues}

The organization of enzymatic capacities for glycolysis (HK, PFK, PK), anaerobic glycolysis (ODH), and aerobic metabolism (CS) in cuttlefish (Figs. 3, 7) corresponds with the accepted view of the aerobic vs. anaerobic design of cephalopod tissues (Hochachka 1995) and, following from the above discussion, illuminates the fuel preferences of cephalopod tissues. The mantle, which powers locomotion, had low HK and CS activities and high PFK, PK, and ODH activities that gear it towards rapid mobilization of stored glycogen to sustain anaerobic burst swimming (Storey and Storey 1983). In comparison, the continually pumping systemic heart relies more on aerobic glucose use, indicated by higher HK and CS activities (Driedzic et al. 1990; Lamarre et al. 2012). While carbohydrates, and amino acids, are important fuels in cephalopod muscle, we revealed a supplementary capacity to use lipid-based fuels, particularly acetoacetate (Fig. 2). Gills appear to use a mix of metabolic fuels, including fatty acids, acetoacetate, and amino acids, as discussed above, as well as glucose via aerobic glycolysis as indicated by appreciable HK activity and relatively low ODH activity (Ballantyne et al. 1981; Lamarre et al. 2012). Digestive gland had low activities of glycolytic enzymes and CS, possibly because of the biosynthetic poise of this tissue, indicated by comparatively high activities of G3PDH and G6PDH under fed conditions (Fig. 5). Amino acids may be preferred over glucose as fuel in digestive gland, given its high AspAT activity (Fig. 6) and vigorous amino acid metabolism (Hochachka et al. 1983); fatty acids may also be important fuels as previously discussed. The metabolism of branchial heart rarely has been studied, but its comparatively high glycolytic enzyme activities suggest reliance upon glucose.

\section{Gluconeogenesis and related biosynthetic pathways}

Few data are available on gluconeogenesis in cephalopods (Ballantyne et al. 1981; Hochachka and Fields 1982). In cuttlefish, G6Pase was detected only in digestive gland, at 
high activities (along with FBPase) (Fig. 4), providing the first evidence that the capacity for de novo glucose synthesis is restricted largely to the digestive gland in cephalopods. However, PEPCK was not reliably detectable in digestive gland (previous measurements are lacking); this could be due to analytical difficulties of determining certain enzyme activities in digestive gland (Ballantyne et al. 1981), or, speculatively, glucose synthesis in cuttlefish digestive gland only proceeds from stored glycogen rather than from non-carbohydrate sources. Indeed, incorporation of radiolabelled amino acids into the gluconeogenic pathway was poor in cephalopod digestive gland (Hochachka and Fields 1982). The possibility that glycerol derived from triacylglycerol catabolism is converted to glucose seems unlikely, considering that G3PDH activity is greatly decreased in digestive gland when triacylglycerol are being mobilized during starvation (Fig. 5). The notion that gluconeogenesis occurs in cephalopod gill (Fields and Hochachka 1982; Hochachka and Fields 1982) was unsupported by the undetectable activities of all gluconeogenic enzymes (Fig. 4).

Unlike other tissues, mantle and systemic heart of cuttlefish showed high PEPCK activities (Fig. 4), despite absent G6Pase. Although squid muscles have low PEPCK activity (Ballantyne et al. 1981), high activities are known in muscle from other molluscs (Crabtree et al. 1972), which contrasts with the absence of PEPCK in vertebrate muscle. The role of PEPCK in cuttlefish muscles is uncertain. Speculatively, given the additional presence in muscles of FBPase (Fig. 4) and substantial glycogen stores (Storey and Storey 1979, 1983), PEPCK could funnel carbon from non-carbohydrate sources towards glycogen synthesis. In fact, amino acids are readily incorporated into the glycogen pool of cephalopod mantles (Hochachka and Fields 1982). Muscle PEPCK also could be involved in cataplerosis (Yang et al. 2009) or in supplying carbon to glycerol production for lipid synthesis, considering the high activities of G3PDH in mantle and systemic heart (Fig. 5) (potentially analogous to the glycerol-producing liver of rainbow smelt; Driedzic 2015).

\section{Starvation responses: glycolytic capacity is downregulated while capacity for lipid-based and amino acid fuel use is retained}

While cuttlefish metabolic organization was mostly unchanged after short-starvation (3-5 days), a general starvation response was observed after long-starvation (12 days): enzymatic capacities for lipid-based and amino acid fuel use were retained while the enzymatic capacity to use glucose was decreased. This general response is consistent with radiolabel and other studies in cephalopods that have suggested that a mix of metabolic fuels is used during early starvation, followed by a greater reliance upon lipids and amino acids in order to conserve carbohydrate stores (digestive gland glycogen is limited; mantle glycogen is reserved for fueling locomotion), and finally a large reliance upon amino acids once lipid stores are exhausted (O'Dor et al. 1984; Castro et al. 1992; Lamarre et al. 2012). In fact, the responses of the ammonia quotient of our study animals suggested a transitory shift to lipid catabolism during short starvation and then to protein catabolism after long starvation, when triacylglycerol became depleted (Lamarre et al. 2016). Layered upon the general response in cuttlefish was a tissue-specific response in which metabolic capacity in digestive gland and mantle appeared to be shut down more than in gill or systemic heart. Digestive gland showed large decreases in glycolytic, aerobic, and biosynthetic enzyme activities after only 3-5 days of starvation, perhaps for energy savings and, given the retained capacities for amino acid, lipid, and gluconeogenic metabolism, as part of a transformation into an exporter of glucose and lipid-based fuels (see below). Mantle, the largest tissue in cephalopods ( $\sim 30-40 \%$ of body mass in cuttlefish; Gabr et al. 1999), showed decreases in many enzyme activities after long starvation (e.g. CPT, CS, G3PDH, HK, PFK, ODH), possibly resulting from starvation-induced decreases in protein synthesis (Lamarre et al. 2016). Conversely, enzymatic capacities in gill and systemic heart were largely unaffected even after long-starvation, aside from the decreased glycolytic capacity, suggesting a greater conservation of metabolism, sustained primarily by lipidbased and amino acid fuels.

The retention of enzymatic capacity to use lipid-based fuels coincided with gradual depletion of triacylglycerol stores in digestive gland (Fig. 1). Acetoacetate may be a key starvation fuel in cuttlefish, based on the maintenance of SKT activity in all tissues, similar to starved vertebrates (Robinson and Williamson 1980). The source of acetoacetate may be the digestive gland, where the increased HOAD activity and maintained SKT activity during starvation is similar to the responses in the ketogenic liver of starved vertebrates (Robinson and Williamson 1980; Foster and Moon 1991) and agrees with a potential role of these enzymes in acetoacetate synthesis from digestive gland lipids in molluscs (Horst and Becker 1986; Horst et al. 1986; Meyer et al. 1986; Stuart and Ballantyne 1996).

The starvation responses of HOAD and CPT activities indicate that fatty acids, presumably released from the digestive gland, are another lipid-based fuel used during starvation, in particular in the gill where HOAD and CPT activities were retained. Curiously, despite absent CPT activity, HOAD activity increased in systemic heart, suggesting some role for cardiac fatty acid oxidation during starvation, possibly involving medium- or short-chain fatty acids (whose use does not require CPT activity). In 
mantle, while HOAD activity was maintained, CPT activity decreased significantly after long-starvation, perhaps because at this point protein catabolism in mantle is fully activated (Lamarre et al. 2012) and lipid stores are depleted. The importance of amino acids as fuel during starvation in mantle, and all other tissues, was supported by the universal maintenance or increase of AspAT activities (Fig. 6), as found previously in cuttlefish (Lamarre et al. 2012) and vertebrates (Horio et al. 1988; Foster and Moon 1991). The retained capacity to use lipid-based fuels after long starvation is somewhat inconsistent with the concurrent exhaustion of triacylglycerol stores (Fig. 1), but we speculate that ketones continue to be synthesized from amino acids (Laffel 1999). Also, other lipid types, common in the digestive glands of cephalopods and mobilized during starvation in cuttlefish (e.g. free fatty acids, diacylglycerol ethers), could be additional sources of lipid fuel (Voogt 1983; Castro et al. 1992).

The starvation-induced decrease in glycolytic enzymatic capacity, especially $\mathrm{HK}$, in cuttlefish tissues is similar to the well-established, rapid (days) downregulation of glycolysis in starved mammals (Cherel et al. 1988; Pilkis et al. 1988; Gibson and Harris 2002) and certain other vertebrates (Moon and Johnston 1980; Blier and Guderley 1986; Foster and Moon 1991; Metón et al. 1999; Secor and Carey 2016). The time scale of the response in cuttlefish, with significant decreases generally occurring only after long-starvation, suggests that circulating glucose is used as fuel early in starvation but later conserved for essential tissues (e.g. brain), similar to mammals (Cahill 2006) and consistent with radiolabel studies on starved octopus (O'Dor et al. 1984). For logistical reasons, we did not measure the enzyme profile of brain, but squid have high HK activities in brain suggesting that glucose is an important fuel (Ballantyne et al. 1981). The early shutdown of glycolytic enzymes in digestive gland while gluconeogenic enzymatic capacity largely was retained is consistent with a strategy of emphasizing de novo glucose synthesis in the gluconeogenic tissue, as in mammals (Pilkis et al. 1988). Whereas in starving mammals multiple glycolytic enzymes are commonly downregulated, in cuttlefish the decreases of glycolytic enzymes downstream of HK were more tissue-specific, perhaps reflecting differences in the use of endogenous glycogen or glycerol liberated from triacylglycerol mobilization. Incorporation of glycerol carbon into glycolysis just prior to the PK node during starvation would be consistent with the finding in most tissues of relatively unchanged activities of G3PDH, which will also sustain glycolytic redox balance. The exception is digestive gland, where G3PDH is greatly decreased, possibly because of this tissue's abolished glycolytic capacity or as part of an energysaving downregulation of lipid biosynthesis (there was also a concomitant decrease in G6PDH activity, which supplies redox potential for lipid synthesis).
Note, the starvation responses of cuttlefish enzyme activities observed in the present study were unlikely to be influenced much by changes in tissue water content, which sometimes accompany food deprivation in animals. In fact, water content in digestive gland and mantle of starving cuttlefish remains unchanged for at least several weeks (Castro et al. 1992), which is beyond the time period of our study. Also, as shown above, the responses we observed reveal pathway- and enzyme-specific patterns within tissues, rather than showing a consistent response across all enzymes that could be expected under the influence of varying water content.

\section{Conclusions and perspectives}

The preferences for metabolic fuels among animals are diverse, depending on the influences of phylogenetic history, environmental conditions, and physiological state (e.g. starvation, exercise) (Moyes et al. 1990; Weber 2011). The use of protein (amino acids) and carbohydrates as key fuels in cephalopods has been attributed to the influences of a rapid-growth life history and the use of high-intensity jet propulsion, respectively, as well as their molluscan heritage (O’Dor and Webber 1986; Hochachka 1995; Lee 1995). Our study is consistent with this view of cephalopod energy metabolism, but strongly supports the notion that lipidbased fuels, including fatty acids and ketone bodies, are important supplements to protein and carbohydrate (Castro et al. 1992; Moltschaniwskyj and Johnston 2006; MorilloVelarde et al. 2013). Lipid-based fuels could be used under routine conditions but appear to be particularly important during starvation, when stored lipids are mobilized from the digestive gland, putatively as acetoacetate and free fatty acids, and glycolytic capacity is decreased in most tissues, perhaps to conserve available glucose.

The sustained capacity to use mobilized lipids during starvation in cuttlefish supports the hypothesis that the lipids in cephalopod digestive glands are stored as an energy reserve (Castro et al. 1992; Seibel et al. 2000; Morillo-Velarde et al. 2013), rather than as an excretory product (Semmens 1998). Indeed, although lipids appear to be slowly catabolized in at least one cephalopod (O'Dor et al. 1984), their high mass-specific energy yield makes them a potent fuel. Thus, stored lipids in cephalopods, which are substantial in many species (Rosa et al. 2005) and might even exist outside the digestive gland in certain species (Moltschaniwskyj and Johnston 2006), may be key for surviving starvation, for example during food shortages or during fasting accompanying prolonged spawning migrations or egg brooding (Wells and Clarke 1996; Seibel et al. 2000; Robison et al. 2014). Specifically, while amino acids are important fuels during starvation, stored lipids in cephalopods may play a vital role in sparing body protein 
from catabolism, as seen in starved vertebrates (Lamarre et al. 2012; Bar 2014).

Overall, we propose a three stage metabolic response to starvation in cephalopods (Table 1) that, in general, resembles the sequential metabolic stages of starvation in mammals and fishes, in which carbohydrates are conserved, lipids sustain starvation, and protein is only used as a last resort once lipid stores fall below a critical level (Black and Love 1986; Cahill 2006; Bar 2014; Secor and Carey 2016). However, in cephalopods, the process may be accelerated, with a relatively early switch to protein catabolism. This is likely because, compared with most vertebrates (especially ectotherms), glycogen and lipid stores are small in cephalopods relative to whole-animal metabolic demand, and the largest glycogen store, in the mantle, seems to be reserved for burst exercise (O'Dor et al. 1984). Meanwhile, body protein is plentiful in cephalopods. However, because mobilization of body protein could impair performance, the accelerated metabolic transition of starved cephalopods may ultimately reflect sensitivity to food deprivation, which, in turn, is a trade-off of their "live-fast, die-young" life history that emphasizes growth over energy storage (O'Dor and Webber 1986). However, exploration of the astounding functional and ecological diversity of cephalopods might provide exceptions, for example among deep-sea species (Seibel et al. 2000; Robison et al. 2014).

Acknowledgments We thank the staff and students at Centro de Ciências do Mar do Algarve for their hospitality and invaluable help during our research, in particular Juan Carlos Capaz, Ana Couto, Ana Oliveira, João Reis, Tania Rodríguez-González, and Cátia Silva. We also thank Dr. Matthew Nosworthy for skilled assistance during a portion of this study and Dr. Kurt Gamperl for loaning us certain equipment. Funding was provided by an NSERC Postdoctoral Fellowship to B.S.-R., an NSERC Canada Graduate Scholarship-Master's and a New Brunswick Innovation Foundation scholarship to N.I.C., and NSERC Discovery Grants to W.R.D., T.J.M., and S.G.L. AVS was supported by Fundação para a Ciência e a Tecnologia through Programa Investigador FCT 2014 (IF/00576/2014) and project SEPIATECH (31-03-05-FEP-2), funded by the Portuguese Government Program PROMAR.

\section{References}

Agnisola C, Driedzic WR, Foster AR, Houlihan DF, Stewart JM (1991) Oxygen consumption, carbon dioxide production and enzyme activities of isolated working Octopus heart. J Exp Biol 157:543-549

Alegre M, Ciudad CJ, Fillat C, Guinovart JJ (1988) Determination of glucose-6-phosphatase activity using the glucose dehydrogenase-coupled reaction. Anal Biochem 173:185-189

Ballantyne JS, Berges JA (1991) Enzyme activities of gill, hepatopancreas, mantle, and adductor muscle of the oyster (Crassostrea virginica) after changes in diet and salinity. Can J Fish Aquat Sci 48:1117-1123 
Ballantyne JS, Moon TW (1985) Hepatopancreas mitochondria from Mytilus edulis: substrate preference and effects of $\mathrm{pH}$ and osmolarity. Mar Biol 87:239-244

Ballantyne JS, Moyes CD (1987) Osmotic effects on fatty acid, pyruvate, and ketone body oxidation in oyster gill mitochondria. Physiol Zool 60:713-721

Ballantyne JS, Storey KB (1983) Mitochondria from the ventricle of the marine clam, Mercenaria mercenaria: substrate preferences and effects of $\mathrm{pH}$ and salt concentration on proline oxidation. Comp Biochem Physiol B 76:133-138

Ballantyne JS, Storey KB (1984) Mitochondria from the hepatopancreas of the marine clam Mercenaria mercenaria: substrate preferences and salt and $\mathrm{pH}$ effects on the oxidation of palmitoyl-Lcarnitine and succinate. J Exp Zool 230:165-174

Ballantyne JS, Hochachka PW, Mommsen TP (1981) Studies on the metabolism of the migratory squid, Loligo opalescens: enzymes of tissues and heart mitochondria. Mar Biol Lett 2:75-85

Bar N (2014) Physiological and hormonal changes during prolonged starvation in fish. Can J Fish Aquat Sci 71:1447-1458

Bar N, Volkoff H (2012) Adaptation of the physiological, endocrine, and digestive system functions to prolonged food deprivation in fish. In: McCue M (ed) Comparative physiology of fasting, starvation, and food limitation. Springer, Berlin, pp 69-89

Beis A, Zammit VA, Newsholme EA (1980) Activities of 3-hydroxybutyrate dehydrogenase, 3-oxoacid CoA-transferase and acetoacetyl-CoA thiolase in relation to ketone-body utilisation in muscles from vertebrates and invertebrates. Eur $\mathrm{J}$ Biochem 104:209-215

Black D, Love RM (1986) The sequential mobilisation and restoration of energy reserves in tissues of Atlantic cod during starvation and refeeding. J Comp Physiol B 156:469-479

Blier P, Guderley H (1986) The enzymatic and metabolic effects of extended food deprivation in Rana pipiens. Physiol Zool 59:230-239

Boucher-Rodoni R, Mangold K (1985) Ammonia excretion during feeding and starvation in Octopus vulgaris. Mar Biol 86:193-197

Brooks SP (1994) A program for analyzing enzyme rate data obtained from a microplate reader. Biotechniques 17:1154-1161

Cahill GF Jr (2006) Fuel metabolism in starvation. Annu Rev Nutr 26:1-22

Castro BG, Garrido JL, Sotelo CG (1992) Changes in composition of digestive gland and mantle muscle of the cuttlefish Sepia officinalis during starvation. Mar Biol 114:11-20

Cherel Y, Burnol AF, Leturque A, Le Maho Y (1988) In vivo glucose utilization in rat tissues during the three phases of starvation. Metabolism 37:1033-1039

Crabtree B, Higgins SJ, Newsholme EA (1972) The activities of pyruvate carboxylase, phosphoenolpyruvate carboxylase and fructose diphosphatase in muscles from vertebrates and invertebrates. Biochem J 130:391-396

Driedzic WR (2015) Rainbow smelt: the unusual case of cryoprotection by sustained glycerol production in an aquatic animal. $\mathrm{J}$ Comp Physiol B 185:487-499

Driedzic WR, Sidell BD, Stewart JM, Johnston IA (1990) Maximal activities of enzymes of energy metabolism in cephalopod systemic and branchial hearts. Physiol Zool 63:615-629

Fields JHA, Hochachka PW (1982) Glucose and proline metabolism in Nautilus. Pac Sci 36:337-341

Fiorito G, Affuso A, Basil J, Cole A, de Girolamo P, D’Angelo L, Dickel L et al (2015) Guidelines for the care and welfare of cephalopods in research - a consensus based on an initiative by CephRes, FELASA and the Boyd Group. Lab Anim 49(2 suppl):1-90

Foster GD, Moon TW (1991) Hypometabolism with fasting in the yellow perch (Perca flavescens): a study of enzymes, hepatocyte metabolism, and tissue size. Physiol Zool 64:259-275
Gabr HR, Hanlon RT, Hanafy MH, El-Etreby SG (1999) Reproductive versus somatic tissue allocation in the cuttlefish Sepia dollfusi Adam (1941). Bull Mar Sci 65:159-173

Gibson DM, Harris RA (2002) Metabolic regulation in mammals. Taylor Francis, London

Grigoriou P, Richardson CA (2009) Effect of body mass, temperature and food deprivation on oxygen consumption rate of common cuttlefish Sepia officinalis. Mar Biol 156:2473-2481

Hochachka PW (1995) Oxygen efficient design of cephalopod muscle metabolism. Mar Freshw Behav Physiol 25:61-67

Hochachka PW, Fields JHA (1982) Arginine, glutamate, and proline as substrates for oxidation and for glycogenesis in cephalopod tissues. Pac Sci 36:325-335

Hochachka PW, Mommsen TP, Storey J, Storey KB, Johansen K, French CJ (1983) The relationship between arginine and proline metabolism in cephalopods. Mar Biol Lett 4:1-21

Horio Y, Tanaka T, Taketoshi M, Uno T, Wada H (1988) Rat cytosolic aspartate aminotransferase: regulation of its mRNA and contribution to gluconeogenesis. J Biochem 103:805-808

Horst C, Becker W (1986) Nutritive medium chain triacylglycerols cause a rapid increase of ketone bodies in the hemolymph of Biomphalaria glabrata (Gastropoda: Pulmonata). Comp Biochem Physiol B 85:875-878

Horst C, Becker W, Kemper A (1986) Short-term alterations of the ketone body content in the hemolymph of Biomphalaria glabrata (Gastropoda: Pulmonata). Comp Biochem Physiol B 84:555-557

Islinger M, Cardoso MJR, Schrader M (2010) Be different-the diversity of peroxisomes in the animal kingdom. Biochim Biophys Acta Cell Res 1803(8):881-897

Laffel L (1999) Ketone bodies: a review of physiology, pathophysiology and application of monitoring to diabetes. Diabetes Metab Res Rev 15:412-426

Lamarre SG, Ditlecadet D, McKenzie DJ, Bonnaud L, Driedzic WR (2012) Mechanisms of protein degradation in mantle muscle and proposed gill remodeling in starved Sepia officinalis. Am J Physiol Reg Integr Comp Physiol 303:R427-R437

Lamarre S, Macmillan L, Morrow GP, Randell E, Pongnopparat T, Brosnan ME, Brosnan JT (2014) An isotope-dilution, GCMS assay for formate and its application to human and animal metabolism. Amino Acids 46:1885-1891

Lamarre SG, MacCormack TJ, Sykes A, Speers-Roesch B, Callaghan NI, Driedzic WR (2016) Metabolic rate and rates of protein turnover in food deprived cuttlefish, Sepia officinalis (Linnaeus 1758). Am J Physiol Reg Integr Comp Physiol. doi:10.1152/ ajpregu.00459.2015

Lee PG (1995) Nutrition of cephalopods: fueling the system. Mar Freshw Behav Physiol 25:35-51

McCue MD (2010) Starvation physiology: reviewing the different strategies animals use to survive a common challenge. Comp Biochem Physiol A 156:1-18

McMurray CH, Blanchflower WJ, Rice DA (1984) Automated kinetic method for D-3-hydroxybutyrate in plasma or serum. Clin Chem 30:421-425

Metón I, Mediavilla D, Caseras A, Cantó E, Fernández F, Baanante IV (1999) Effect of diet composition and ration size on key enzyme activities of glycolysis-gluconeogenesis, the pentose phosphate pathway and amino acid metabolism in liver of gilthead sea bream (Sparus aurata). Br J Nutr 82:223-232

Meyer R, Becker W, Klimkewitz M (1986) Investigations on the ketone body metabolism in Biomphalaria glabrata: influence of starvation and of infection with Schistosoma mansoni. J Comp Physiol B 156:563-571

Moltschaniwskyj N, Johnston D (2006) Evidence that lipid can be digested by the dumpling squid Euprymna tasmanica, but is not stored in the digestive gland. Mar Biol 149:565-572 
Mommsen TP, Hochachka PW (1981) Respiratory and enzymatic properties of squid heart mitochondria. Eur $\mathrm{J}$ Biochem 120:345-350

Mommsen TP, Ballantyne J, MacDonald D, Gosline J, Hochachka PW (1981) Analogues of red and white muscle in squid mantle. Proc Natl Acad Sci 78:3274-3278

Mommsen TP, Hochachka PW, French CJ (1983) Metabolism of arginine, proline, and ornithine in tissues of the squid, Illex illecebrosus. Can J Zool 61:1835-1846

Moon TW, Johnston IA (1980) Starvation and the activities of glycolytic and gluconeogenic enzymes in skeletal muscles and liver of the plaice, Pleuronectes platessa. J Comp Physiol 136:31-38

Morillo-Velarde PS, Valverde JC, Serra Llinares RM, García BG (2013) Changes in lipid composition of different tissues of common octopus (Octopus vulgaris) during short-term starvation. Aquacult Res 44:1177-1189

Moyes CD, Suarez RK, Hochachka PW, Ballantyne JS (1990) A comparison of fuel preferences of mitochondria from vertebrates and invertebrates. Can J Zool 68:1337-1349

Navarro JC, Monroig O, Sykes AV (2014) Nutrition as a key factor for cephalopod aquaculture. In: Iglesias J, Fuentes L, Villanueva R (eds) Cephalopod culture. Springer, New York, pp 77-95

Newsholme EA, Crabtree B (1986) Maximum catalytic activity of some key enzymes in provision of physiologically useful information about metabolic fluxes. J Exp Zool 239:159-167

O’Dor RK, Webber DM (1986) The constraints on cephalopods: why squid aren't fish. Can J Zool 64:1591-1605

O’Dor RK, Mangold K, Boucher-Rodoni R, Wells MJ, Wells J (1984) Nutrient absorption, storage and remobilization in Octopus vulgaris. Mar Behav Physiol 11:239-258

Pande SV, Lee TS, Murthy MS (1990) Freeze-thawing causes masking of membrane-bound outer carnitine palmitoyltransferase activity: implications for studies on carnitine palmitoyltransferases deficiency. BBA Lipid Lipid Met 1044:262-268

Pilkis SJ, El-Maghrabi MR, Claus TH (1988) Hormonal regulation of hepatic gluconeogenesis and glycolysis. Annu Rev Biochem 57:755-783

Robinson AM, Williamson DH (1980) Physiological roles of ketone bodies as substrates and signals in mammalian tissues. Physiol Rev 60:143-187

Robison B, Seibel B, Drazen J (2014) Deep-sea octopus (Graneledone boreopacifica) conducts the longest-known egg-brooding period of any animal. PLoS One 9:e103437

Rosa R, Pereira J, Nunes ML (2005) Biochemical composition of cephalopods with different life strategies, with special reference to a giant squid, Architeuthis sp. Mar Biol 146:739-751

Secor SM, Carey HV (2016) Integrative physiology of fasting. Compr Physiol 6:773-825

Seibel BA, Hochberg FG, Carlini DB (2000) Life history of Gonatus onyx (Cephalopoda: Teuthoidea): deep-sea spawning and postspawning egg care. Mar Biol 137:519-526
Semmens JM (1998) An examination of the role of the digestive gland of two loliginid squids, with respect to lipid: storage or excretion? Proc Roy Soc Lond B 265:1685-1690

Sidell BD, Driedzic WR, Stowe DB, Johnston IA (1987) Biochemical correlations of power development and metabolic fuel preferenda in fish hearts. Physiol Zool 60:221-232

Speers-Roesch B, Treberg JR (2010) The unusual energy metabolism of elasmobranch fishes. Comp Biochem Physiol A 155:417-434

Stewart JM, Brass ME, Carlin RC, Black H (1992) Maximal enzyme activities of energy production pathways in the heart, hepatopancreas, and white muscle of the giant scallop (Placopecten magellanicus) and lobster (Homarus americanus). Can J Zool 70:720-724

Stio M, Vanni P, Pinzauti G (1988) A continuous spectrophotometric assay for the enzymatic marker glucose 6-phosphatase. Anal Biochem 174:32-37

Storey KB, Storey JM (1979) Octopine metabolism in the cuttlefish, Sepia officinalis: octopine production by muscle and its role as an aerobic substrate for non-muscular tissues. J Comp Physiol 131:311-319

Storey KB, Storey JM (1983) Carbohydrate metabolism in cephalopod molluscs. In: Hochachka PW, Wilbur KM (eds) The mollusca, vol 1. Academic Press, New York, pp 91-136

Storey KB, Storey JM, Johansen K, Hochachka PW (1979) Octopine metabolism in Sepia officinalis: effect of hypoxia and metabolite loads on the blood levels of octopine and related compounds. Can J Zool 57:2331-2336

Stuart JA, Ballantyne JS (1996) Correlation of environment and phylogeny with the expression of $\beta$-hydroxybutyrate dehydrogenase in the mollusca. Comp Biochem Physiol B 114:153-160

Suarez RK (2012) Energy and metabolism. Compr Physiol 2:2527-2540

Sykes AV, Domingues P, Andrade JP (2014) Sepia officinalis. In: Iglesias J, Fuentes L, Villanueva R (eds) Cephalopod culture. Springer, New York, pp 175-204

Voogt PA (1983) Lipids: their distribution and metabolism. In: Hochachka PW, Wilbur KM (eds) The mollusca, vol 1. Academic Press, New York, pp 329-370

Weber JM (2011) Metabolic fuels: regulating fluxes to select mix. J Exp Biol 214:286-294

Wells MJ, Clarke A (1996) Energetics: the costs of living and reproducing for an individual cephalopod. Phil Trans R Soc B 351:1083-1104

Yang J, Kalhan SC, Hanson RW (2009) What is the metabolic role of phosphoenolpyruvate carboxykinase? J Biol Chem 284:27025-27029

Zammit VA, Beis A, Newsholme EA (1979) The role of 3-oxo acidCoA transferase in the regulation of ketogenesis in the liver. FEBS Lett 103:212-215 